University of Nebraska - Lincoln

DigitalCommons@University of Nebraska - Lincoln

1981

\title{
Determination of Age and Whelping Dates of Live Red Fox pups
}

\author{
Alan B. Sargeant \\ USGS Northern Prairie Wildlife Research Center \\ Stephen H. Allen \\ USGS Northern Prairie Wildlife Research Center \\ Douglas $\mathrm{H}$. Johnson \\ USGS Northern Prairie Wildlife Research Center, Douglas_H_Johnson@usgs.gov
}

Follow this and additional works at: https://digitalcommons.unl.edu/usgsnpwrc

Part of the Other International and Area Studies Commons

Sargeant, Alan B.; Allen, Stephen H.; and Johnson, Douglas H., "Determination of Age and Whelping Dates of Live Red Fox pups" (1981). USGS Northern Prairie Wildlife Research Center. 213.

https://digitalcommons.unl.edu/usgsnpwrc/213

This Article is brought to you for free and open access by the US Geological Survey at DigitalCommons@University of Nebraska - Lincoln. It has been accepted for inclusion in USGS Northern Prairie Wildlife Research Center by an authorized administrator of DigitalCommons@University of Nebraska - Lincoln. 
This article is a U.S. government work, and is not subject to copyright in the United States.

\section{DETERMINATION OF AGE AND WHELPING DATES OF LIVE RED FOX PUPS}

ALAN B. SARGEANT, Northern Prairie Wildlife Research Center, Jamestown, ND 58401; STEPHEN H. ALLEN, North Dakota Game and Fish Department, Bismarck, ND 58501; and DOUGLAS H. JOHNSON, Northern Prairie Wildlife Research Center, Jamestown, ND 58401.

Public concern for large carnivores, high longhair fur prices, and recent findings of predator-prey investigations have increased interest in the management of red foxes (Vulpes vulpes). A technique for assigning individuals to age-classes is necessary to understand the population dynamics and behavioral interactions of this species. Previous studies have focused on separating young from adults and on estimating age of adults (Harris 1978), but a need exists to know age of 
live pups. Pup age data can be used to ascertain conception and whelping dates and age-specific behavior at dens. Age of captured live pups can be estimated from morphological changes (Linhart 1968), hind-foot length (Johnson et al. 1975), zygomatic breadth (Storm et al. 1976), and body weight (Sargeant 1978). These methods are not widely used and, except for hind-foot length, their accuracy has not been documented. Methods that avoid capturing pups would be particularly useful in some studies, but none is available. In this paper we evaluate the use of hind-foot length, pelage color, and body size for estimating the age of red fox pups, and apply these criteria to determine whelping dates of red foxes in the northern Great Plains.

\section{METHODS AND STUDY AREAS}

We used 3 data sets: (1) measurements obtained during 1969-71 of penreared pups held captive in outdoor pens at the Northern Prairie Wildlife Research Center, Jamestown, North Dakota, or outdoors at the Dakota Zoo, Bismarck, North Dakota; (2) measurements obtained during 1969-73 of pups captured at natural dens in eastern North Dakota, primarily in Barnes, Kidder and Stutsman counties; and (3) visual observations made during 1969-70 of wild pups at numerous dens in Iowa, North Dakota, and South Dakota.

The captive foxes were 28 wild-caught pups obtained at 5-8 weeks of age and fed simulated natural diets, and 9 knownage pups born in captivity. Hind-foot length, pelage color, and body size (relative to adults) were recorded at weekly intervals. Equations for estimating age from hind-foot length were developed from these data (Johnson et al. 1975). These equations require mean hind-foot lengths at both birth and maturity.
The 2nd data set involved 900 pups captured during April through July 196973 at 260 rearing dens. Most dens were found during annual mid-May and midJune systematic aerial searches of 693 $\mathrm{km}^{2}$ study areas (Sargeant et al. 1975). We measured the length of the right hind foot of each pup and recorded pelage color and body size. These pups provided the data for establishing relationships between estimated age (based on hind-foot length) and pelage color and body size.

The 3rd data set consisted of observations of pelage color and body size of one or more pups at 764 dens (including the 260 dens mentioned above) in Iowa, North Dakota, and South Dakota that were visited by us or by cooperators. The Iowa dens were the same dens reported by Storm et al. (1976). North and South Dakota were stratified into areas east and west of the Missouri River. Survey participants were asked to select 1 of 5 color and 1 of 7 size categories that best described the $\operatorname{pup}(\mathrm{s})$ seen at each den.

Whelping dates were calculated by first establishing the age of each litter from the average estimated age of all littermates determined from hind-foot length or from a description of pelage color and body size, and then subtracting that age from the date of capture.

\section{RESULTS}

\section{Hind-foot Length Age Determination}

Johnson et al. (1975) found that hindfoot length was excellent for estimating age of pups to about 80 days of age (Table $1)$, but that the reliability of this criterion was questionable for older animals. Hind-foot lengths of newborn red foxes were nearly identical between sexes and similar among regions: $29 \mathrm{~mm}$ among 6 newborn foxes in North Dakota (this study); $28 \mathrm{~mm}$ among 21 full-term fetuses 
Table 1. Estimated age of male and female red fox pups based on length of hind foot (from Johnson et al. 1975).

\begin{tabular}{ccc}
\hline \multirow{2}{*}{$\begin{array}{c}\text { Hind-foot length } \\
(\mathrm{mm})\end{array}$} & \multicolumn{2}{c}{ Estimated age (days) } \\
\cline { 2 - 3 } 30 & Male & Female \\
\hline 40 & 1.3 & 1.7 \\
50 & 9.5 & 10.1 \\
60 & 16.5 & 17.3 \\
70 & 22.9 & 23.9 \\
80 & 28.9 & 30.1 \\
90 & 34.7 & 36.2 \\
100 & 40.5 & 42.4 \\
110 & 46.5 & 48.9 \\
120 & 52.8 & 55.9 \\
130 & 59.7 & 63.7 \\
140 & 67.5 & 73.1 \\
& 76.9 & 85.2 \\
\hline
\end{tabular}

in New York (Layne and McKeon 1956); and $29 \mathrm{~mm}$ among 18 full-term fetuses in Illinois and Wisconsin (Storm and Ables 1966). On the other hand, sexual dimorphism affects hind-foot length at an early age (Table 1), and asymptotic hind-foot length varies among regions (McIntosh 1963, Fairley 1970, Storm et al. 1976). Mean asymptotic hind-foot lengths of 116 male and 85 female adult foxes, trapped or hunter-shot in North Dakota, were $169.9 \mathrm{~mm}(\mathrm{SD}=6.1)$ for males and 161.5 $\mathrm{mm}(\mathrm{SD}=5.2)$ for females.

There was little variation in growth rates among siblings, hence determined age of a single pup is a fairly accurate measurement of age of the litter. We examined 142 litters with 3 or more pups, and $81 \%$ had a within-litter standard deviation in estimated age of 4.0 days or less. Six litters with greatest spread of pup ages had standard deviations of 9.115.0 days. We believe that each of these 6 litters included pups of 2 vixens sharing the same den, as communal dens are common among red foxes (Sheldon 1950, Storm et al. 1976).

\section{Visual Age Determination}

Pelage color changes among our penreared pups were similar to those de- scribed by Linhart (1968). From birth to 14 weeks the pups exhibited 3 distinct color phases: dark gray, pale buff, and red. In addition, there were 2 intermediate phases, 1 each in the transitions from gray to buff and from buff to red. Thus, we categorized the 5 color phases as gray, gray-brown, buff, buff-red, and red.

Seventy-six captive and wild North Dakota pups were classed as gray; the oldest was 40 days old. Pups cannot walk until about 3 weeks old (Linhart 1968), and observations of our captive foxes indicated that they did not spend time outside dens until they were 4-5 weeks old. Thus, most gray pups seen outside dens are $28-40$ days old. The color change from gray to buff was completed in less than 2 weeks. The average age of 119 gray-brown pups was 40 days (range 3560 days). Pups remained buff colored for about 3 weeks and then gradually became red as guard hairs appeared and the woolly puppy appearance was replaced by the sleek adult look. Buff- and buffred-colored pups averaged 49 and 69 days old, respectively. The youngest red pup was 61 days old. Because adult foxes also are red, this color phase is only useful to establish that pups are a minimum age or older.

Visual estimates of pup body size are subjective; therefore, we used this criterion primarily to confirm the accuracy of the pelage color descriptions and to indicate possible growth abnormalities. We established 7 size categories: 1/8, 1/4, 1/3, 1/2, $2 / 3,3 / 4$, and full grown.

Six of the 35 possible pelage colorbody size descriptions accounted for $88 \%$ of the pups handled at dens in eastern North Dakota (Fig. 1). These were the only descriptions subsequently considered for use in estimating age, which restricted analysis to easily distinguishable color-size descriptions and resulted in 


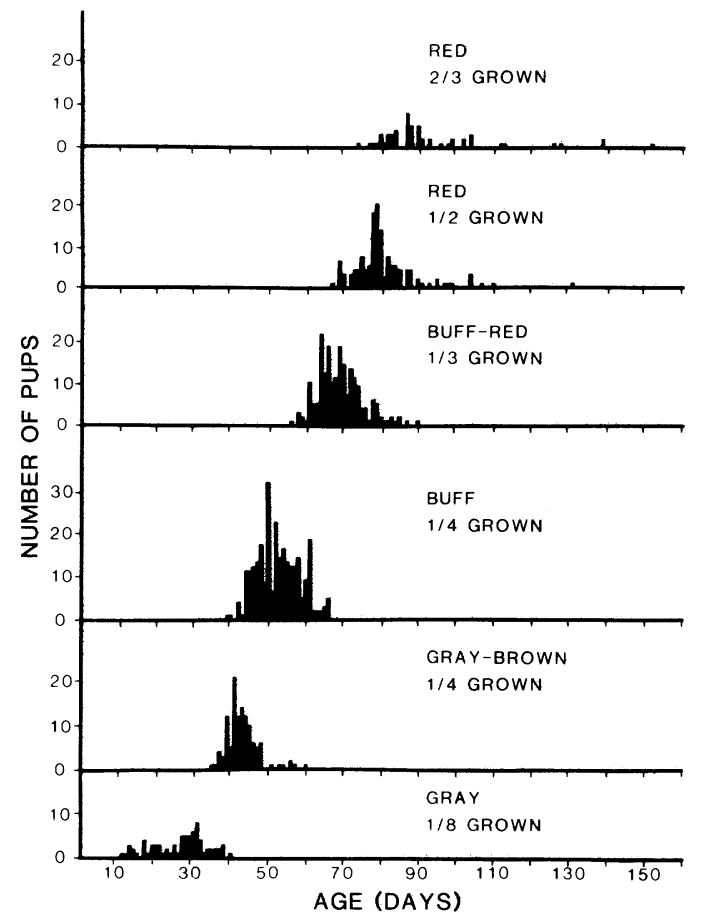

Fig. 1. Relationship of 6 most commonly used descriptions of red fox pup pelage color-body size to age of the pups estimated from hind-foot length.

excluding atypical pups. Three of these age-classes, however, involved small gray or large red pups and were inadequately sampled or open-ended. Therefore, we could most accurately estimate age only from the 3 intermediate categories: gray-brown $-1 / 4$ grown, buff-1/4 grown, and buff-red-1 $1 / 3$ grown. Two of these involved pups of about the same size, but with easily distinguished pelage colors. Mean ages of pups in these 3 categories were 43,53 , and 69 days old, respectively.

\section{Determination of Whelping Dates}

Whelping dates can be established by back-dating pup age from date of capture. Whelping dates of eastern North Dakota red foxes during 1969-73 based on hindfoot lengths of pups from litters with mean age 80 days or less ranged from 3

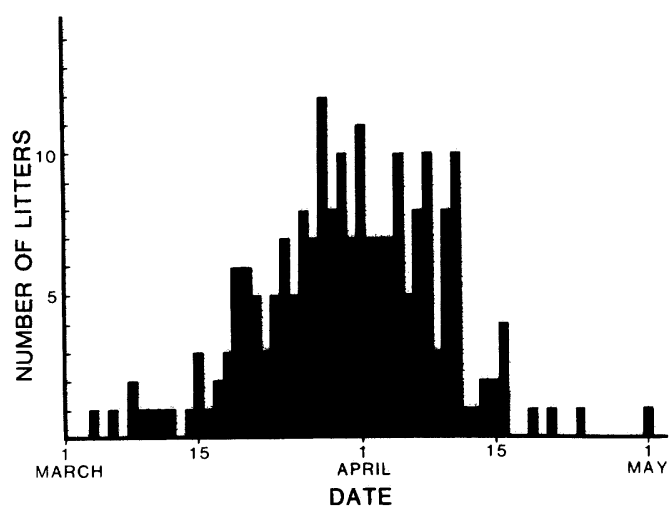

Fig. 2. Whelping dates of red fox litters, 80 days old or younger, caught at 207 dens in eastern North Dakota during 1969-73. The mean whelping date was 31 March.

March to 1 May (58 days) and averaged 31 March (Fig. 2). Mean annual whelping dates for each of the 5 years ranged from 28 March to 1 April.

From observations of pelage color and body size, we were able to estimate mean whelping dates of pups from the 5 areas in Iowa and North and South Dakota for 1969-70. Only pups in the 3 intermediate color-size categories were used in the calculations, which included $40 \%$ of the observations of pups. The mean whelping dates of foxes in Iowa and both eastern and western South Dakota were nearly the same (16, 14, and 14 March, respectively). The mean whelping dates of foxes in eastern and western North Dakota were 2 and 3 April, which are similar to results based on hind-foot length.

\section{DISCUSSION}

An obvious advantage to estimating age from hind-foot length or visual observations of pelage color and body size is that it can be done without harming the foxes. The hind-foot method is particularly accurate for determining age of pups up to 80 days old (Johnson et al. 1975). The hind foot is easily measured and its rapid daily growth (about $1.4 \mathrm{~mm} /$ day) re- 
duces effects of small measurement errors. The visual method of estimating pup age, although less accurate than the hind-foot method, is well suited to studies in which dens cannot be disturbed, or to extensive or long-term surveys. For use in establishing whelping dates, relatively large numbers of observations should be made, and sampling should span the dates when pups of a particular color-size group can be observed. The spread of whelping dates in eastern North Dakota indicates this is about a 2month period.

Several factors affect application of our methods. Fox size varies geographically, and therefore mean adult hind-foot lengths should be determined for each area in which the hind-foot age determination equations are to be applied. Pelage color of adult foxes also varies among regions. The clearly defined gray-brown and buff categories of most prairie foxes will likely require different interpretation in regions with darker foxes. Finally, the exclusion from data sets of obviously aberrant pups or of seldom-used colorsize categories will improve the accuracy of dating reproductive or behavioral events.

Breeding and whelping chronologies of wild red foxes are only generally known because most estimates are based on chance observation of breeding or whelping. The whelping dates we estimated from fox hind-foot lengths in eastern North Dakota show that pups were born from early March to late April. The extreme dates, however, may reflect small errors in estimating age of individual pups. The mean whelping date varied only 5 days among the 5 years studied. Our visual methods provided results similar to the hind-foot method, and verify differences in whelping dates of foxes in nearby regions that may be related to lat- itude and climate. Mean whelping dates of the foxes in Iowa and South Dakota were similar to each other, but about 18 days earlier than in North Dakota.

The only comparative data on whelping dates in the regions studied are provided by Storm et al. (1976). These investigators independently estimated conception dates for the same Iowa foxes used in the present study on the basis of zygomatic breadth, and concluded that the peak of conception occurred during 17-24 January and ranged from early December to mid-February. By adding 52 days for gestation (Asdell 1964), the peak of whelping would have occurred from 10 to 17 March, which encompasses our estimate of 16 March based on pelage color and body size. Further, their wide range of conception dates is similar to the range in whelping dates that we found for eastern North Dakota.

Acknowledgments.-We appreciate the assistance of individuals from the U.S. Fish and Wildlife Service; Iowa Conservation Commission; North Dakota Game and Fish Department; South Dakota Department of Game, Fish and Parks; and University of Minnesota, who cooperated in the den questionnaire survey. We thank D. T. Allen, R. T. Eberhardt, E. K. Fritzell, T. C. Hendrickson, W. H. Howell, R. E. Nelson, W. K. Pfeifer, G. L. Rohde, and J. F. Wolf, who assisted in locating fox dens in eastern North Dakota and who helped obtain pups for examination, and R. J. Greenwood for manuscript review.

\section{LITERATURE CITED}

AsDell, S. A. 1964. Patterns of mammalian reproduction. Cornell Univ. Press, Ithaca, N.Y. $670 \mathrm{pp}$.

FAIRLEY, J. S. 1970. The food, reproduction, form, growth and development of the fox (Vulpes vulpes L.) in northeast Ireland. Proc. Royal Irish Acad. 69:B103-B137. 
Harris, S. 1978. Age determination in the red fox (Vulpes vulpes)-An evaluation of technique efficiency as applied to a sample of suburban foxes. J. Zool. Lond. 184:91-117.

Johnson, D. H., A. B. SARGEANT, AND S. H. Allen. 1975. Fitting Richards' curve to data of diverse origins. Growth 39:315-330.

LAYNE, J. N., AND W. H. MCKEON. 1956. Notes on the development of the red fox fetus. N.Y. Fish and Game J. 3:120-128.

LinharT, S. B. 1968. Dentition and pelage in the juvenile red fox (Vulpes vulpes). J. Mammal. 49:526-528.

MCINTOSH, D. L. 1963. Reproduction and growth of the fox in the Canberra District. CSIRO Wildl. Res. 8:132-141.

SARgEANT, A. B. 1978. Red fox prey demands and implications to prairie duck production. J. Wildl. Manage. 42:520-527.
- W. K. Pfeifer, and S. H. Allen. 1975. A spring aerial census of red foxes in North Dakota. J. Wildl. Manage. 39:30-39.

Sheldon, W. 1950. Denning habits and home range of red foxes in New York state. J. Wildl. Manage. 14:33-42.

Storm, G. L., AND E. D. ABles. 1966. Notes on newborn and full-term wild red foxes. J. Mammal. 47:116-118.

, R. D. ANdrews, R. L. Phillips, R. A. BISHOP, D. B. SinIFF, AND J. R. TESTER. 1976. Morphology, reproduction, dispersal, and mortality of midwestern red fox populations. Wildl. Monogr. 49. 82pp.

Received 11 April 1980

Accepted September 1980. 